\title{
Textos religiosos e práticas cotidianas: leitura de aspectos simbólicos da Irmandade de Penitentes Peregrinos Públicos - Juazeiro do Norte-CE
}

\author{
Anna Christina Farias de Carvalho ${ }^{1}$; Maria Cristina Delmondes Nascimento ${ }^{2}$; Miriam Delmondes Batista ${ }^{3}$ \\ Gislene Farias de Oliveira ${ }^{4}$
}

Resumo: Neste artigo discutimos, a partir da análise de dois textos religiosos, as relações que se estabelecem entre a cosmovisão de um grupo religioso do Cariri cearense - Irmandade de Penitentes Peregrinos Público - em seus aspectos simbólicos, e os textos Machadinha de Noé e Missão Abreviada. Pretendeu-se enfatizar os aspectos que dizem respeito à concepção de mundo dos integrantes da referida irmandade e suas práticas cotidianas. A metodologia utilizada foi a História oral, através de entrevistas, história de vida e observação direta. Concluímos que os escritos referidos se revelaram textos fundantes das práticas e manifestações religiosas do grupo, normalizadores das práticas sociais e promotores da coesão grupal através da noção de pertencimento.

Palavras-chave: Irmandade de leigos. Textos religiosos. Catolicismo diferenciado. Cariri cearense.

\section{Religious texts and daily practices: Reading of symbolic aspects of the Penitents Public Pilgrims Brotherhood in Juazeiro do Norte-CE}

\begin{abstract}
This article discusses, from two religious texts analysis, the relationships established between the worldview of a religious group Ceará Cariri - Brotherhood of Penitents Public Pilgrims - in its symbolic aspects, and Hatchet texts of Noah and Mission Abridged. It was intended to emphasize the aspects that concern the design of the world of that brotherhood members and their daily practices. The methodology used was the oral history through interviews, life story and direct observation. We conclude that the writings referred proved foundational texts of religious practices and manifestations of the group, normalizing social practices and promoters of group cohesion through the sense of belonging.
\end{abstract}

Keywords: Brotherhood of the laity. religious texts. differentiated Catholicism. Cariri Cearense.

\section{Introdução}

Neste artigo pretendemos refletir, a partir da análise de dois textos religiosos, as relações normativas que se estabelecem entre a cosmovisão de um grupo religioso do Cariri cearense Irmandade de Penitentes Peregrinos Público - e suas práticas cotidianas norteadas pelo folheto Machadinha de Noé e o sermonário Missão Abrevidada.

\footnotetext{
${ }^{1}$ Professora Aposentada da Universidade Regional do Cariri - URCA; Doutora em Sociologia pela Universidade Federal da Paraíba - UFPB; Pesquisadora do Núcleo de Estudos em Ciência, Espiritualidade e Filosofia - NECEF/URCA. E-mail: anna_crica@ hotmail.com;

${ }^{2}$ Mestre em Ciências da Educação pela Universidad Hispano Guarani. Especialização em Politicas Educativas e Docência do Ensino Superior pela Faculdade de Formação de professores de Araripina - FAFOPA. Especialização em Educação Ambiental pela FAFOPA. Possui graduação em Ciências Biológicas pela Universidade Federal do Vale do São Francisco, graduação em Licenciatura em Pedagogia pela Faculdade Evangélica do Piaú e graduação em Engenharia Agronômica Pela Faculdade De Ciências Agrárias De Araripina. Professora do Instituto Educacional Ruymar Gomes no ensino superior, professora da Escola Dionisio Bom de Oliveira no fundamental I. Palestrante - WEJ Consultoria, Professora do CETECS BRASIL. Contato: Cristina_delmondes@hotmail.com.

${ }^{3}$ Mestranda em educação pela Anne Sullivan niversity; Contato: miriamdelmondes@ hotmail.com;

${ }^{4}$ Psicóloga, Doutora em Psicologia Social pela Universidade Federal da Paraíba - UFPB. Pós doutorado em Ciências da saúde pela Faculdade de Medicina do ABC - SP. E-mail: gislenefarias@gmail.com.
} 
Neste sentido, procuramos interpretar as práticas religiosas enquanto aspecto significativo para a compreensão da cultura religiosa do Cariri cearense, centrando a análise no simbólico, conceito que entendemos, propicia uma maior visibilidade para discutirmos as experiências religiosas do povo caririense.

Campo em processo de constante movimento e reinvenções, o simbólico engloba, especialmente no Cariri cearense, uma diversidade de práticas sociais e produções culturais que vão desde a dança ${ }^{1}$ à construção de discursos ressignificados, tendo nos rituais a base do arcabouço de crenças que constituem a identidade dos diversos grupos religiosos, como os analisados em nossa tese de doutoramento: Irmandade de Penitentes Peregrinos Públicos; Irmandade de Penitentes de São Gonçalo (Juazeiro do Norte); Irmandade de Penitentes do Sítio Lagoa; Irmandade de Penitentes da Cruz (Barbalha) ${ }^{2}$.

O simbólico aqui enfocado relaciona-se diretamente com a produção social de sentido, de inter-relação com a realidade, que norteia um modo de ser e estar no mundo, de pertencer a um mundo onde há uma linha divisória entre o nós e os outros.

No referido trabalho, utilizamos o conceito de catolicismo diferenciado para compreendermos o fenômeno religioso delimitado em nosso estudo - Irmandades de Penitentes. Entendemos catolicismo diferenciado como:

[...] um campo de práticas e representações religiosas que não dependem diretamente de agentes formais (instituídos) para estabelecer esta relação entre o homem e o sagrado, compreendendo uma autoprodução e reinvenção de práticas e representações que se contrapõem à produção instituída por especialistas (CARVALHO, 2005, p.5).

Neste aspecto recuperamos as análises de Bourdieu (1998, 1999) que discute a concepção de "campo religioso", lembrando um campo de batalha onde há o enfrentamento entre os sacerdotes (agentes especializados) e os leigos (destituídos do capital religioso). Os integrantes das irmandades de leigos analisadas em nossa tese caracterizam-se como sendo católicos, praticam uma religiosidade repleta de ritos, práticas e discursos que não segue a ortodoxia clerical católica, entretanto tem a Igreja Católica como referência. Romarias, auflagelação, dança votiva, devoção aos santos não canonizados oficialmente (Padre Cícero

\footnotetext{
${ }^{1}$ Dança votiva praticada por integrantes da Irmandade de Penitentes de São Gonçalo, Juazeiro do Norte-CE.

${ }^{2}$ Sob o Signo da Fé e da Mística: um estudo das irmandades de penitentes no cariri cearense (2005).
} 
como exemplo mais expressivo), Renovação do Sagrado Coração de Jesus ${ }^{3}$, mendicância itinerante, práticas mágico-religiosas de cura, entre outras expressões de religiosidade, que no nosso entender, torna visível o campo do catolicismo diferenciado proposto em nossa tese.

Entretanto, tais condutas religiosas atípicas convergem para crenças orientadas por valores religiosos católicos como a crença na Santíssima Trindade, na Igreja Católica, devoção a santos e santas católicos, prática da oração, caridade e penitência como fontes de salvação eterna. Para tais grupos de penitentes, a salvação é garantida através de práticas penitenciais que vão desde o castigo corporal ou disciplina, ao jejum, voto de castidade ou renúncia ao convívio social: "Maltratar o corpo para elevar o espírito, é um preceito presente e vivenciado no catolicismo diferenciado caririense" (CARVALHO, 2005, p. 11).

De caráter etnográfico, na pesquisa de campo utilizamos as narrativas orais e observação direta, além de recursos como gravação áudio-visual e fotografias, dos rituais e práticas que nos foi permitido acompanhar. Pensamos que, teorizar as práticas simbólicas observadas, delimitar em abstrações acadêmicas de modo fechado tais vivências, seria uma contraposição metodológica, já que nos propusemos partir das narrativas dos devotos.

Em relação à Irmandade de Penitentes Peregrinos Público, a pesquisa de campo processou-se em dois momentos: no primeiro momento, coletamos dados quando o líder espiritual da irmandade, Mestre José, estava vivo (1998 e 1999) num segundo momento, após seu falecimento (2002).

\section{A Penitência Peregrina}

A comunidade dos Penitentes Peregrinos Públicos, localizada no Bairro Tiradentes, na periferia do município de Juazeiro do Norte-CE, tem como meta básica a redenção ou salvação através da penitência. Tal propósito exclui qualquer tipo de conforto material: não possuem energia elétrica nem água encanada em suas moradas, não dão muita importância à higiene pessoal como formalmente entendemos, não trabalham e não aceitam dinheiro, nem como esmola, não fumam, dançam ou bebem, só andam a pé, a maioria do grupo não é alfabetizado

\footnotetext{
${ }^{3}$ Prática ritual instituída por Padre Cícero no Cariri cearense.
} 
Id on Line Revista Multidisciplinar e de Psicoloqia

Id on Line Multidisciplinary Journal and Psycology

(CARVALHO, 2005). As cores azul e branca são utilizadas nas vestimentas, símbolos como as bandeiras e na pintura das casas, representando "o sofrimento da Mãe das Dores", segundo Mestre José4.

O mito e a história são aspectos relevantes para compreendermos o imaginário dos Penitentes Peregrinos. A localização da gênese do grupo converge para as narrativas que delineiam significações e possibilidades possíveis. Uma delas se refere a Padre Cícero. Segundo Mestre José, foi Meu Padim Ciço que colocou em seu coração a vontade de peregrinar para Juazeiro do Norte.

Mestre José nos pareceu um profeta sertanejo do século XIX, a exemplo de Antônio Conselheiro $^{5}$, e assim como o Conselheiro, pregava o fim do mundo, a preparação para a morte, a penitência. Sua figura, curvada e com certa imponência e carisma, com barbas e cabelos longos, transmitia um profundo desprezo às coisas materiais. Suas práticas religiosas, baseadas na penitência como principal meta de vida com vistas à salvação, tinha nas escrituras sagradas (especialmente a Missão Abreviada) a base normativa como única a seguir.

Seu discurso, caracterizado por metáforas bíblicas, reinterpretadas através da linguagem popular, apresentava uma clareza cristalina em alguns momentos e em outros, um intricado labirinto de significações. Falava de suas crenças de forma segura e tranqüila não impondo suas verdades.

A partir da narrativa de Mestre José, inferimos que a Irmandade tem sua origem na década de setenta, quando ele e sua esposa (D. Regina) vieram para Juazeiro do Norte.

Apesar de todo seu carisma, seus adeptos eram poucos, em torno de 25 na primeira visita (1998); uns 15 na segunda (1999) e umas 08 a 10 pessoas (2002) entre homens e mulheres. Uma quantificação mais precisa do grupo fica difícil, na medida em que seus integrantes não falam abertamente sobre esta questão. Os números acima são os observados na pesquisa de campo, pois segundo Mestre José6:

Nós não damos essa comunidade de gente não, que é muito pesada a cruz. O povo não agüenta a cruz, ai se deixa, vão ganhar o que querem. A cruz é pesada, é por isso que nós não damos quantos tem, nem quantos somos. Se fosse obra de interesse, ai vinha muita gente, hoje;

\footnotetext{
${ }^{4}$ A mãe de Jesus, Maria, Cf. entrevista datada de maio de 1999.

${ }^{5}$ CUNHA refere que Antonio Conselheiro trazia consigo dois livros: a Missão Abreviada e as Horas Marianas. CUNHA, Euclides. Os sertões:campanha de Canudos. São Paulo:Abril Cultural, 1982. p. 124

${ }^{6}$ Entrevista concedida em maio de 1999.
} 
amanhã quando você perguntasse, já tinha outro tanto, muito mais. É por isso que nós não dizemos, porque a quantidade é invisível.

Em sua fala, não havia referência à política ou injustiça social, pois a salvação era seu objetivo, e esta só é alcançada através de Deus e não através da vida material que tenta os homens, conduzindo-os ao caminho da destruição espiritual.

Todos os integrantes masculinos do grupo se autodenominam José Ave de Jesus e as mulheres Maria Ave de Jesus, segundo Mestre José ${ }^{7}$ :

É como os pássaros, tem que comer o grão, tem que comer a semente, tem que beber a água, tem que fazer a existência de sua regência de pássaro. E a gente também, para seguir como os pássaros, também comer e beber e viver no meio de vocês, aqui. Você dá um confeito, outro dá um punhado de farinha... Vida de pássaro, não é a vida de santo ...

Em público, os integrantes do grupo, até o falecimento de Mestre José, levavam bandeiras com os seguintes dados: iniciais dos seus nomes (J. A. J - José Ave de Jesus), da Irmandade (I.R.S.S. - Irmandade do Santíssimo Sacramento), número e iniciais do grupo (n. x P.P.P. - Penitente Peregrino Público). O cotidiano do grupo é marcado pela penitência itinerante: peregrinação pela cidade em busca da caridade ou orando diante das estações do caminho do Horto, assistência à missa aos domingos, (em pé ou de joelhos em frente à entrada da matriz de Nossa Senhora das Dores), orações diárias, privações.

Um dos fatores que observamos foi que o grupo vem paulatinamente perdendo seus adeptos. Apontamos como fator decisivo para esta situação, a práticas religiosas e cotidianas rígidas, norteadas, sobretudo, pelo sermonário Missão Abreviada.

\section{A Reinterpretação de Textos Religiosos}

A crença escatológica no Fim do Mundo está presente em várias expressões religiosas (Canudos, Pedra Bonita, Contestado, Borboletas Azuis, para citar alguns), constituindo-se como crença fundante no imaginário religioso dos Penitentes Peregrinos Públicos, pois

\footnotetext{
${ }^{7}$ Entrevista concedida por Mestre José Ave de Jesus em dezembro de 1998.
} 
partimos das falas de seus adeptos, mescladas de passagens bíblicas apocalípticas, Antigo Testamento, prédicas do Padre Cícero, figura central na devoção dos Penitentes Peregrinos Públicos, em especial, referências a passagens da Missão Abreviada.

Na visão dos penitentes, a espera pela vinda de Cristo se apresenta como uma metáfora próxima à vivência dos devotos, em sua grande maioria de origem rural, como podemos observar na narrativa de Mestre José sobre a preparação para a vinda do Messias ${ }^{8}$ :

\begin{abstract}
Para colher, nós plantamos uma roça e começa do começo, limpa o mato, para esperar por quem? Por Jesus, né? Enquanto ele não manda a obra de misericórdia, nós estamos esperando, quando ele manda, nós vamos plantar e cultivar para esperar o fruto é assim, como vocês. Vocês não estão trabalhando? Para tentar colher o fruto tem que ter paciência e saber se dedicar, saber enviar. [...] É como a vida de Jesus. A vida de Jesus hoje é teatro. A vida de Jesus só está naqueles que morrem para o mundo, ai já é um grande teatro. [...] Jesus foi um desprezado. Quando ele andou 33 anos, ele não achou onde inclinar a cabeça.
\end{abstract}

Ao observarmos o sistema de interpretação de Mestre José acerca do fim do mundo, observamos que o campo religioso dos Penitentes Peregrinos apresenta uma intrincada complexidade simbólica que tem como suporte passagens da Bíblia, da Missão Abreviada e da Machadinha de Noé. Há uma fusão de elementos bíblicos com elementos da geografia de Juazeiro do Norte, com recursos de experiências cotidianas que nas palavras de Ramos (2000, p. 136) pode ser assim resumido:

\footnotetext{
O lugar sagrado é, também, uma espacialidade que se constrói como tática de sobrevivência. Além de expressar (e alimentar) uma urdidura de crenças e valores, a cartografia da fé emerge como uma forma de amenizar as dores do cotidiano. $\mathrm{O}$ território religioso não é somente uma porta que liga esse mundo com o outro, nem somente uma fonte de revelações. Ao ganhar a condição de território religioso, Juazeiro passa a ser um lugar sobre o qual o devoto tem forte esperança de eliminar ou diminuir as dores e desventuras de cada dia, como doença falta de trabalho, falta de chuva ou ainda desavenças ligadas ao casamento ou a questões em torno da posse de terras.
}

Consideramos que o discurso enunciado por Mestre José se insere numa construção histórica e representa uma justificação de seu universo sagrado, evocando significados cifrados, inteligíveis para o imaginário da comunidade que o construiu.

\footnotetext{
${ }^{8}$ Entrevista datada de 08 de dezembro de 1998.
} 
Id on Line Revista Multidisciplinar e de Psicoloqia

Id on Line Multidisciplinary Journal and Psycology

Dessa forma, há uma reinterpretação que representa uma ressignificação da realidade, uma visão de mundo compartilhada pelos membros da Irmandade de Penitentes Peregrinos.

O discurso religioso dos integrantes da Irmandade de Penitentes Peregrinos demonstra a reelaboração do discurso da Igreja Católica, a partir de dois textos: $A$ Machadinha de Noé e a Missão Abreviada, que se revelaram enquanto suporte para essa vivência religiosa. Essas duas narrativas textuais são importantes fontes de reconstrução de aspectos da cultura religiosa da Irmandade de Penitentes Peregrinos. Tais textos contêm registros de valores e regras comportamentais que nos permite reconstruir cosmovisões, valores e práticas representativas do grupo a que são atribuídos, embora o corpus textual esteja aberto a uma variedade de possíveis decodificações.

Neste sentido, procuramos analisar aspectos do imaginário religioso do grupo por entendermos, a partir das narrativas dos devotos, que ambos os textos são estruturantes de uma concepção de realidade e padrões de convivência, que são vivenciados cotidianamente pelos Penitentes Peregrinos, representando sua visão de mundo, se tornando inclusive objeto de devoção, como é o caso do sermonário Missão Abreviada.

\section{A Machadinha de Noé e a Escatologia Apocalíptica}

No texto Machadinha de Noé $e^{9}$ cuja autoria é creditada a Padre Cícero é profetizada a iminente destruição do mundo. É interessante comentar, que os sinais do final dos tempos não está numa linguagem cifrada como a do Apocalipse de São João, mas numa linguagem decodificada, interpretada, indicando regras de condutas a serem vivenciadas pelos fiéis; normas norteadoras das práticas cotidianas.

Vejamos como Mestre José se posiciona diante da crença do Fim do Mundo e quais os deveres do cristão para salvar-se do Inferno $^{10}$ :

[...] Daqui a uns dias vocês estarão correndo atrás de quem tem amparo ai como uma parede, pra vocês se ampararem nela, pra ver se escapa, nem que seja do inferno.

\footnotetext{
${ }^{9}$ Utilizamos nesse texto a cópia que nos foi fornecida pelo grupo datada de 1931. Entretanto em 2005, conseguimos um folheto datado de 1911, entretanto

${ }^{10}$ Entrevista datada de 08 de dezembro de 1998
} 
Porque a decorrência agora vai ser muito tenebrosa, tempo do Pai foi de quatro mil anos, o tempo do Filho não vai completar dois mil.

O negócio ai vai tudo ser mudado. Não sou eu dizendo que você não trabalhe mais pra ganhar o pão, fazer sua remissão. Mas sou eu dizendo assim: se lembre dos trabalhos, se lembre do seu espírito, de sua alma, o corpo é matéria. Qualquer hora Deus chama e o cabra vai pro fundo da terra, enquanto ele é queimado pelo fogo. Naquele tempo de água e agora é fogo. Quando foi pra limpar tudo, não vai ficar nada de bagulho da terra. É o mundo do Pai, quatro mil anos e não completa dois mil do Filho, o tempo do Espírito Santo é para sempre [...].

A Machadinha de Noé representa um dos vários textos apocalípticos marcados por simbologias e profecias. O título do texto evoca, na tradição Bíblica, o fim do mundo pelo dilúvio, a história de Noé e sua família, a concepção de que poucos serão salvos, poucos são os escolhidos, conforme a Machadinha: "só aqueles que se converterem e se arrependerem dos seus pecados e buscarem a Deus".

Como a maioria dos textos apocalípticos, a Machadinha de Noé tem sua origem na Bíblia cristã, no livro Apocalipse de São João ou Livro da Revelação ${ }^{11}$. Como no texto de São João, os sinais do final dos tempos (guerras, fome, pestilência, terremotos, decadência moral e renúncia da fé cristã, transformações políticas mundiais), e as predições sobre a vinda do Anticristo (a personificação do mal, o Diabo, o caos) e o retorno de Cristo ${ }^{12}$ (o Messias, o Juiz), estão presentes em grande parte das narrativas apocalípticas. Na Missão Abreviada, no item Meditação $11^{\circ}$ - Sobre o juízo final, os sinais do final dos tempos se apresentam a partir de previsões, linguagem frequente nestes textos proféticos:

Considera pecador, que este mundo brevemente há de acabar; e perto do seu fim ele há de ser atribulado com grandes pestes, fomes, guerras, inundações e terremotos. Tudo isto é o principio de grandes dores e grandes males: todo este mundo há de ser abrasado com espantosos redemoinhos de fogo, e será reduzido a um montão de cinzas com todos os seus viventes! (COUTO, 1868, p. 72)

O texto transcrito em seguida foi nos fornecido por integrante do grupo com a seguinte advertência:

\footnotetext{
${ }^{11} \mathrm{O}$ texto do Apocalipse difunde uma mensagem Judaico-Cristã, já que está baseado no Livro de Enoc, "escrito judaico não inspirado". Cf. BÍBLIA SAGRADA. 26. ed. Tradução Centro Bíblico Católico. São Paulo:Ave Maria, 1979. p.1556. (Rodapé).

${ }^{12}$ Os últimos tempos que vão da Ascensão à vinda de Cristo: "Mil anos mostram a amplidão vitoriosa do cristianismo que é a mais profunda realidade que encobre todo o curso da história do reino messiânico". Cf. Bíblia Sagrada, Op. cit. p.1576 (Rodapé).
} 
É uma profecia, a Machadinha de Noé, como uma bola de ouro. Quem possuir a Machadinha deveria segurar como se segura uma bola de ouro. Mas ela é que nem a Santa Missão, escuta o que estou dizendo.

Quem fez foi meu Padrinho Ciço Romão Batista e num tem um grão de areia de mentira, é ouro puro, ouro de lei. O que está escrito tem de acontecer, que o homem queira e que não queira, que o Diabo queira e que não queira, tem que acontecer o que está escrito. ${ }^{13}$

\section{Machadinha de Noé ${ }^{14}$}

Aviso do Padre Cícero Romão Batista Sobre os principais acontecimentos do fim do Mundo

Meus caros amiguinhos ${ }^{15}$ é chegado o último momento de dar-vos o meu aviso a todos os habitantes da face da terra, como os sinais prediletos por Nosso Senhor Jesus Cristo, antes da sua sagrada morte paixão, convertei-vos e arrependei-vos dos vossos grandes pecados. Disse: Nosso Senhor Jesus Cristo quando vires, pestilências, fomes, guerras, revoluções, nação contra a mesma nação, (guerras civis), reino contra reino, que são as novas formas de governos, repúblicas, ditaduras, bolchevismo ou comunismo, como hoje está convertida a Rússia em um governo anticristão, forma de governo esta que brevemente se espalhará por toda face da terra, terremoto, inundações, coisas espantosas, diversos fenômenos, estas coisas são princípios de dores, e sinais do fim do mundo, ou destruição dos homens sobre toda face da terra, tudo isto devido ao pecado e a corrupção, cada dia os homens vão se afastando de Deus e de sua santa religião o que amam os homens de hoje? A vaidade, a orgia, as riquezas e a toda sorte de corrupção, disse, Jesus Cristo, que nos últimos tempos havia de multiplicar-se a iniquidade e o amor de muitos havia de esfriar; quer dizer que a santa religião cristã seria abandonada, a terra atualmente esta cheia de falsas religiões de falsos profetas, de falsos cristos as doutrinas anticristãs estão sendo propagadas em toda parte como a tal espiritismo ou feiticismo moderno levantado em todos os países do mundo, tudo isso são os verdadeiros sinais do fim do mundo, porém disse Jesus Cristo, que o evangelho do reino de Deus seria pregado em todo mundo, que é a religião cristã, então chegai o fim, olhe! Que estou os avisando! Convertei-vos e arrependei-vos hoje mesmo, que é chegado o tempo do juízo final e do ajuste de contas, e quem não se arrepender mais tarde corará sem remédio, ai de vós pecadores, ai! De vós ó ricos usurários, ai! Daqueles que vive embriagado com o álcool, embriagado com as vaidades do mundo, ai! De vós ó assassinos, verdadeiros filhos do diabo, se não arrependerdes a tua alma está no inferno, ai! De vós ó ladrão que roubas o alheio, Deus bem sabe que tu és um ladrão, o teu lugar maldito se não arrependeres é no fogo do inferno, ai! De vós feiticeiros, que enganas a humanidade de Deus não terás o perdão, maldito serás, ai do mau filho! Ai da má filha! Ai do mentiroso e do que levanta falso testemunho contra seu próximo, ai do cachaceiro que é a verdadeira raposa do inferno, ai de vós ateus! Diabos encarados que negam a existência de Deus, ai! De quem pratica o mal, arrependi-vos e confessai-vos de vossos pecados e dêem glórias a Deus do Céu, rezai os vossos rosários, ouvi a santa missa, praticai caridade, amai o vosso próximo abandonai o orgulho e a soberba, credes em Nosso Senhor Jesus Cristo que é nosso salvador, que morreu por nós na cruz para nos remir e salvar, ai

\footnotetext{
${ }^{13}$ Entrevista concedida em 20 de agosto de 2002.

${ }^{14}$ Texto mimeografado e xerocado, com ano se $1931 \mathrm{com}$ autoria referida a Padre Cícero, entregue a nós por um dos integrantes da irmandade. Entretanto, após a defesa da tese, continuamos nossas pesquisas e encontramos um folheto datado de 1911.

${ }^{15}$ Carvalho faz um comentário acerca dessa evocação de Padre Cícero em relação aos seus devotos: "Um Padre Cícero que chamava os fiéis de amiguinhos, em que a autoridade se diluía e em que aflorava o pastor..." Cf. CARVALHO, Gilmar de. Madeira matriz: cultura e memória. São Paulo:Annablume, 1998. p. 57.
} 
meus caros amiguinhos, aviso a todos que em breve antes do dia final o mundo será conflagrado por uma grande guerra, isso acontecerá depois do ano de 1930, guerra que consumirá três partes de gênero humano. "Aqui faço ponto."

$\mathrm{X} . \dagger \mathrm{X} . \dagger \mathrm{X} . \dagger$ porque serão confundidos, porém os justos serão salvos. Jesus Cristo virá buscá-los, nos dias destas letras "X. A. I. X. L. 3" 19 séculos de morte de Jesus Cristo, os mortos se ressuscitarão antes deste acontecimento, os homens cada vez mais se afastarão de Deus e da sua santa religião no Brasil e levantará um governo que perseguirá a religião católica, será restaurada a monarquia no Brasil por poucos tempos e terminará com uma Ditadura militar na Espanha será proclamada a República, morrerá dois papas e será assassinado pelos cardeais e ressuscitará depois. MISTÉRIO DIABÓLICO questão religiosa que se comentará por toda Europa, América e a Ásia, manifestação do anti-Cristo e confusão da humanidade naquele dia. A Inglaterra será quase toda submergida por grandes temporais e terremotos nas costas da Itália destruirão muitas ilhas e cidades, ai de ti ó Roma serás danificada por uma grande catástrofe o mundo inteiro lamentará sobre ti.

Lisboa será arrasada por dois grandes terremotos. New York será arrasada por um momento por um grande incêndio acompanhado de um temporal. A Rússia continuará com a perseguição religiosa até que apague o nome Deus, de lá sairá o anti-Cristo e aparecerá brevemente espalhará os emissários por toda parte do mundo, a doutrina do anti-Cristo é o espiritismo, ele perseguirá a catolicismo o protestantismo, o judaísmo, naqueles dias começará então a guerra civil ou consumidora, antes da guerra o povo dirá que há paz e segurança, mas imediatamente virá repentina destruição; palavras do apóstolo São Paulo, então se cumprirá as profecias de Isaias e Daniel o mundo inteiro será esfacelado pela guerra civil, guerra que começará pelos povos civilizados e estenderá até os povos bárbaros, a guerra civil começará na Rússia brigará nação contra nação, nação com a mesmo nação, guerra contra guerra, guerra em terra, guerras nos mares, guerras nos ares, batalhas contra batalhas, serão grandes os exércitos, grandes as tropas o povo revoltar-se-á contra os governos e chefes de suas nações o pobre revoltar-se-á contra o rico e o nobre, os matarão, os vencerão, os ricos e poderosos e nobres estarão escondidos nas cavernas dos montes e rochedos, porém de nenhuma forma escaparão, naqueles dias será terrível a fome, depois passará a peste o que escapar da guerra ou a espada não escapará da fome, o que escapar da fome não escapará da peste por fora assolará a espada e por dentro a fome e a peste; eis meus caros amiguinhos o fim dos homens neste mundo, serão destruídas todas as cidades, com todas suas riquezas, com todas as suas glorias serão reduzidas a cinzas, eis a ira de Deus todo poderoso derramando contra os homens devido o orgulho e a soberba a terra ficará deserta e inabitada. O Céu escurecerá, a lua não dará mais sua claridade.

Porém meus amiguinhos aqueles que se converterem e se arrependerem dos seus pecados e buscarem a Deus, Nosso Senhor Jesus Cristo, estes não perecerá nem um só cabelo da cabeça todos se salvarão destas pragas, só serão participantes delas os maus e os ímpios que não se arrependerem para darem glória a Deus do céu.

Meus irmãos convertei-vos e arrependei-vos hoje mesmo: porque todos vós um dia irão prestar contas dos vossos pecados e crimes perante a face do reto juiz Jesus Cristo o filho de Deus O REI DOS REIS E SENHOR DOS SENHORES.

Olhem com tempo antes a todos estou avisando e continuo avisar, vou dar-vos o verdadeiro sinal do anti-Cristo, vem como um sacerdote a sua doutrina é o espiritismo, o seu sinal é o vermelho ou encarnado, ele diz: ser Jesus Cristo que foi novamente reencarnado, que não há dia de juízo e nem ressurreição dos mortos que não existe inferno e o demônio, ele é o inimigo capital da religião católica e protestante tratará 
de apagar o nome de Jesus Cristo, perseguirá os israelitas, a doutrina anticristã, três partes do povo abraçará, ele fará grandes milagres e progressos, fará descer fogo do céu, a vista dos homens, (aqui faço ponto final)

Olhem! O meu aviso ninguém se engane que o tempo é chegado, porém muitos não acreditarão brevemente eu mandarei circular o meu segundo aviso com relação à vinda de Elias e Henoc, que serão combatidos pelo ministro de satanás. Sairá em Março de 1931 depois que o céu fizer sinal. Deus vos guarde.

Padre Cícero Romão Batista

Juazeiro - Ceará

A profecia evoca uma visão escatológica, anunciando a época do fim do mundo numa data cifrada, cercada de mistério: "Jesus Cristo virá buscá-los, nos dias destas letras 'X. A. I. X. L.3' 19 séculos de morte de Jesus Cristo, os mortos se ressuscitarão antes deste acontecimento...", refletindo semelhanças com o texto bíblico que também não fornece uma indicação precisa sobre este fato. Segundo o Evangelho de São Mateus 24:36, Jesus assim se posiciona: "Quanto aquele dia e àquela hora, ninguém o sabe, nem mesmo os anjos do céu, mas somente o Pai ${ }^{16 ،}$.

O texto acima é rico em elementos que permitem a construção de aspectos da cultura religiosa da comunidade em estudo. Originado das condições sociais do período referido, pode ser visto como parte estruturante das relações significantes que o produziram. Do simbolismo e das normas de conduta que atravessam todo o texto, emerge uma concepção de realidade e padrões de convivência, que são vivenciadas cotidianamente pelos Penitentes Peregrinos, através das práticas sociais já citadas, representando sua visão de mundo.

Enquanto texto religioso apresenta interconecções espaço-temporais que se aproxima da mitologia. Contudo, levando em conta seu significado simbólico, entendemos que o texto esta contextualizado no interior da experiência real da comunidade e/ou agente que o produziu.

\section{A Missão Abreviada e a Noção de Relíquia}

A mística que envolve a Missão Abreviada pode ser aproximada de uma verdadeira devoção, pois envolve além do culto ao livro enquanto representação do sagrado, atitudes e ritos de veneração. Esta inter-relação promove uma negociação com o sagrado que reverte o

\footnotetext{
${ }^{16}$ Cf. Bíblia Sagrada, Op. cit. p. 1314. É acrescentado em rodapé: "Alguns manuscritos trazem ainda, nem mesmo o Filho".
} 
objeto em relíquia, enquanto parte do sagrado. No imaginário dos Penitentes Peregrinos, encarna o próprio Deus objetivado. O livro nos foi mostrado, não sem antes termos sido advertidos que não poderíamos pegar ou tocar "na Santa Missão Abreviada", só os devotos podem manusear o livro. Perguntamos sobre o significado daquele livro para o grupo, a resposta veio rápida e segura, num tom de exaltação mística:

[...] nós seguimos por ele. Eu não sigo um passo que não seja por ele. Olhe, a Santa Missão Abreviada é Deus Verdadeiro, Deus. Como se a senhora tivesse a oportunidade de pegar no livro, fechar a mão e dizer: Oh! Meu Deus, meus Deus, graças a Deus tô pegado com meu Deus. Porque disse Jesus Cristo: eu com luz o firmamento e a luz do sol e eu em Verdade na terra na mão do homem da boa vontade, e a Verdade é a Santa Missão. Ela não tem um grão de areia de farta, nem de mentira, nem de erro, não senhora, nem um piu.

[...] Jesus Cristo, Nosso Senhor Jesus Cristo, não é mais que a Santa Missão e a Santa Missão não é mais do que Jesus (...) ${ }^{17}$

O exemplar da Missão Abreviada da irmandade encontra-se na residência de Mestre José, em sua cama, juntamente com a Bíblia e o retrato de Padre Cícero. Perguntamos sobre o significado daquele conjunto religioso: "Representa um mistério", nos foi respondido. Aqui mais uma vez observamos a reelaboração do discurso religioso promovido pelos Penitentes Peregrinos. Os mistérios dolorosos dizem respeito ao sofrimento da Virgem Maria diante da Paixão de Cristo, que comentaremos adiante.

Conforme anteriormente citado, há referências que Antônio Conselheiro conservava na cabeceira este livro, uma espécie de guia para pregações, usado também por Padre Ibiapina e Padre Cícero. Os textos religiosos da Missão Abreviada inspiraram práticas religiosas no interior nordestino, sendo amplamente divulgados pelas Santas Missões.

Embora discordemos de alguns argumentos, a análise feita por Hoornaert (1972, p. 77 86) sobre a Missão Abreviada ${ }^{18}$ nos deu indicações para o aprofundamento deste importante documento fundante da religiosidade nordestina. $\mathrm{O}$ referido estudo apresenta considerações acerca da formação religiosa no interior do Nordeste, estabelecendo contraposições entre a verdadeira e falsa religião, ou como a Igreja Católica desqualifica as práticas religiosas populares nordestinas a partir de uma visão eurocêntrica. Hoornaert identifica no texto uma

\footnotetext{
${ }^{17}$ Entrevista concedida em 20 de agosto de 2002.

${ }^{18}$ A edição que estamos comentando é a $6^{\text {a }}$ publicada em 1868, a mesma que os Penitentes Peregrinos nos mostrou.
} 
Id on Line Revista Multidisciplinar e de Psicoloqia

Id on Line Multidisciplinary Journal and Psycology

marcante influência penitencial onde a mortificação do corpo e do espírito é extremamente valorizada.

O livro Missão Abreviada é denominado pelo autor de bíblia do Nordeste devido sua grande absorção pelas camadas populares, cujos preceitos permanecem vivos na memória popular e até hoje inspiram práticas religiosas e determinam condutas sociais, como as exemplificadas pelos grupos analisados neste trabalho.

Sendo um estudo datado, as reflexões por ele produzidas investem na argumentação de que as práticas religiosas reproduzidas cotidianamente pelos leigos se configuram como negação às instituídas pela Igreja Católica. Neste sentido, não evidencia que essas práticas e discursos sendo oriundas de diferentes perspectivas culturais (européia, indígena e africana), inclusive de matriz Tridentina, antes de negarem, convergem e reafirmam as práticas católicas, sendo reinventadas pelas várias experiências religiosas vivenciadas no Nordeste.

Os escritos da Missão Abreviada, por exemplo, foram repassados tanto por agentes institucionalizados (missionários), como agentes leigos (beatos, conselheiros), sendo estas pregações incorporadas as tradições rituais, orais e escritas ${ }^{19}$ durante o processo de construção do catolicismo diferenciado no Cariri cearense.

O sermonário Missão Abreviada é de autoria do padre português Manuel Gonçalves Couto e tem como sugestivo subtítulo: Para Despertar os Descuidados Converter os Pecadores e Sustentar o Fructo das Missões. Na capa explicita também seus objetivos: É destinado este livro para fazer oração, e instrucções ao povo, particularmente povo d'Aldeia. Obra utilíssima para os parochos, para os capellães. Para qualquer sacerdote que deseja salvar almas, $e$ finalmente para qualquer pessoa que faz oração publica.

Entretanto, no imaginário do grupo, a Missão Abreviada ou "Livro de Todos os Livros, foi feito pela inspiração de Nosso Senhor Jesus Cristo, escrito pelos dois evangelistas: São Lucas e São Mateus ${ }^{20 "}$. Percebemos aqui a construção de uma religiosidade que ao articular tradições orais e escritas incorporam e transmitem versões que transcendem os códigos eruditos e caracteriza-se por uma temporalidade e narrativa passível de reelaborações.

\footnotetext{
${ }^{19}$ Uma interessante análise acerca de folhetos religiosos encontra-se em: BRITO, Gilmário Moreira. Culturas e linguagens em folhetos religiosos do Nordeste:inter-relações, escrituras, oralidade, gestualidade, visualidade. 2001. 292f. (Doutorado em História Social) - Pontifícia Universidade Católica de São Paulo, São Paulo. (Mimeo.).

${ }^{20}$ Entrevista concedida em 20 de agosto de 2002.
} 
Id on Line Revista Multidisciplinar e de Psicoloqia

Id on Line Multidisciplinary Journal and Psycology

A Missão Abreviada é um livro marcadamente devocional utilizado como texto básico nas pregações e sermões das Santas Missões que durante o século XIX percorreram os sertões nordestinos. De acordo com Montenegro (1973, p. 13-14):

No século passado, circulavam nos sertões os livros 'Missões Abreviadas' e 'Mística Cidade de Deus'. O primeiro constituía uma espécie de breviário do sertanejo. Contava fatos relacionados com castigos e sofrimentos impostos aos transgressores da lei divina. O segundo, atribuído à venerável Maria de Jesus Águeda, foi condenado por Inocêncio XI, em 1681, por estar inçado de proposições errôneas no concernente às revelações.

Ao longo de suas mais de 700 páginas, a Missão Abreviada exorta o devoto à prática das fundamentais virtudes cristãs, base do catolicismo devocional - penitência, obediência, paciência, humildade e caridade.

Para aprimorar estas virtudes, o cristão é instigado à prática da mais mencionada norma de procedimento em todo o texto: a penitência - como exemplificamos em seguida:

[...] Penitência meus irmão; sem penitência não se salvam os pecadores; se não fizerdes penitência todos vos perdereis, diz a Escritura Sagrada. É necessário pois, jejuar quando o manda a Santa Igreja, tendo já a idade, para assim fazer penitência pelos pecados; e peca mortalmente quem não cumpre com este preceito, podendo: além d'isto também é necessário sofrer e padecer com boa vontade, e até com gosto, outras penitências que Deus manda, como são trabalho e incômodos, dores e enfermidades, e tudo aquilo que mortifica o nosso corpo, para assim purificarmos a nossa alma, e preparar-nos para entrar algum dia no Reino dos Céus ${ }^{21}$.

[...] Um verdadeiro cristão, é exato nos seus deveres, é uma pessoa humilde, obediente, cheia de caridade para com o seu próximo; é paciente, justa e penitente [...]

A mortificação do corpo para salvar o espírito é certamente o princípio que rege a vida do cristão. Neste contexto, o sermonário Missão Abreviada se caracteriza como um texto de orientação bastante rígida, parte do preceito de que todos são pecadores e a salvação depende, sobretudo, da mortificação. O mundo se define como uma Teocracia, onde Deus, Juiz Absoluto, se apresenta como sendo um Deus severo, porém onipresente, onisciente e onipotente. Sob a ótica da salvação, alguns elementos, de cunho penitencial e resignado pietismo, predominam no texto enquanto concepções norteadoras do devoto:

\footnotetext{
21 Instrução 26 - Sem Penitência não se Salvam os Pecadores Segunda Parte, Op. cit. p. 207

22 Instrução 35, - Deus quer Salvar todas as Gentes, Terceira Parte, Op. cit. p. 354.
} 
Id on Line Revista Multidisciplinar e de Psicoloqia

Id on Line Multidisciplinary Journal and Psycology

- Mortificar os sentidos externos;

- Viver o espírito do Evangelho;

Desprezar o mundo material;

Praticar as virtudes cristãs;

Imitar a vida de Jesus Cristo e demais santos católicos.

É significativo que localizemos, já nas primeiras linhas do texto, a premissa fundamental do catolicismo leigo: "[...] qualquer homem ou mulher que saiba ler bem, e de uma vida exemplar [...], na falta do sacerdote pode repassar os ensinamentos do livro (COUTO, 1868, p. 7)".

Vejamos outro trecho onde os leigos estão autorizados a repassarem bens simbólicos de salvação:

Quem faz o voto acima dito em favor das almas, fica com a liberdade de aplicá-lo em particular por quem quiser, e obrigações livres. Sendo Sacerdote, goza de altar privilegiado nos dias em que o fizer; bem como qualquer pessoa que o fizer, goza de privilegio de livrar do purgatório tantas almas, quantas missas ouvir nas segundas feiras $^{23}$.

As orientações defendidas pelo Padre Manuel Couto (e certamente autorizadas pela Igreja Católica, como está explicitado na capa: Com auctorisação de S. ). Ex $x^{a}$ o Snr. Bispo d'esta Diocese nos remete a algumas considerações acerca das circunstâncias do estabelecimento do catolicismo no Brasil.

Segundo algumas análises, como a de Hoornaert (1982), subordinado ao regime de padroado $^{24}$ o catolicismo implantado no Brasil, caracterizou-se pela descentralização e fragilidade da organização de seu aparato religioso, propiciando a emergência do denominado catolicismo popular, identificado com práticas religiosas onde a população não necessitava de uma intervenção direta de especialistas da Igreja para sua concretização, tais como: devoções, romarias, santos padroeiros, festas, procissões, criação e manutenção de santuários e capelas.

Outra visão deste processo remete-nos a questão da natureza da população colonial. Souza (1986, p. 80) centra sua tese na noção de que a especificidade da natureza da população

\footnotetext{
${ }^{23}$ Op. Cit., p.10.

${ }^{24}$ "O direito de padroado foi cedido pelo papa ao rei português com a incumbência de promover a organização da Igreja nas terras 'descobertas', de sorte que foi por intermédio deste Padroado que a expansão do catolicismo no Brasil foi firmada" . HOORNAERT, Eduardo. A Igreja no Brasil-colônia: 1550-1800. São Paulo:Brasiliense, 1982. p. 12.
} 
Id on Line Revista Multidisciplinar e de Psicoloqia

Id on Line Multidisciplinary Journal and Psycology

colonial (brancos em sua maioria degredados, índios e negros), desenvolveu uma "convivência e interpenetração de populações de procedência várias e credos diversos. Múltiplas tradições culturais desaguavam, assim na feitiçaria e na religiosidade popular”.

Desta forma, a autora aponta os limites da análise deste processo, centrada na idéia de “"cristianização imperfeita' das massas do Ocidente europeu ${ }^{25 ”}$ ". Segundo Mello e Souza, sobretudo na Europa do século XVII, dois sistemas de crenças conviviam no universo da cristandade: a dos teólogos e a dos crentes, apesar dos esforços da Igreja para romper com esta cultura arcaizante que perdurava há séculos no interior das populações cristianizadas; pois a concepção mágica do mundo atravessava todas as classes sociais, sendo que o "conhecimento empírico era partilhado por todos e a física galileana só dizia respeito a uma minoria de sábios ${ }^{26 "}$.

Não é objetivo desse trabalho, contemporizar com as abordagens referidas, o que estamos analisando é o que se manteve culturalmente no catolicismo vivenciado no Cariri cearense que transcende expressões institucionalizadas, ou seja, estruturas históricas que se fazem presentes na atualidade. Práticas sociais como os santuários, festas, irmandades e textos religiosos como a Missão Abreviada, são representativos dessas estruturas históricas que, contemporâneas, estruturam visões de mundo e práticas culturais.

A predominância do culto aos santos no catolicismo diferenciado estrutura-se a partir da crença do devoto na força milagrosa representada pela imagética religiosa. $\mathrm{O}$ devoto acredita que a imagem do santo se constitua a materialização do sagrado, dessa forma, ele constrói uma inter-relação de promessas e cultos, expressa numa relação de troca e fidelidade entre o devoto e o santo.

No sermonário Missão Abreviada, destaca-se não essa particularidade de realização de milagres pelos santos, mas a identificação do martírio sofrido por eles como exemplo a ser seguido. Dai a grande relevância que tem a vida dos santos. É neste sentido, que o culto aos santos prevalece como orientação para os devotos no sermonário.

Observamos que as vinte e uma hagiografias ${ }^{27}$ contemplam em especial a vida de santos que praticavam a mortificação do corpo e espírito. Vejamos alguns exemplos:

\footnotetext{
${ }^{25}$ Idem, Ibid.

${ }^{26}$ Idem, p.88

${ }^{27}$ Além dos acima citados, temos ainda: S. Agostinho; S. Pedro d'Alcântara; S. Maria do Egypto; S. Vicente; S. Barbara; Patriarcha S.

Domingos; S. Ignácio de Loyola; S. Maria Magdalena de Pazzi; S. Affonso; S. Catarina de Sena; S. Francisco d'Assis; S. Bruno; S. Catharina Mártir; S. Luzia Virgem e S. Antonio.
} 
S. Francisco Xavier: "Em certa ocasião indo de jornada, apertadamente se atou com uns cordões cheios de nós; assim o praticou para não dar passo algum sem se mortificar" 28.

S. Pelagia: "... foram tão rigorosos os jejuns, tão grandes as suas abstinências, e tão áspero os seus cilícios, que só tinha a pele e os ossos; estava tão desfigurada e mortificada, que tinha os olhos sumidos!". ${ }^{29}$

S. Thereza de Jesus: "Vestia-se de um cilício de folha de flandres cheio de buracos, deixando a todo n'uma chaga; também tomava rigorosas disciplinas e algumas vezes se mortificava com molho de urtigas..." 30

S. André Corsino: "Jejuava a pão e água três dias na semana; domava e castigava seu corpo com áspero cilício e rigorosas disciplinas ${ }^{31 " .}$

S. Philippe Nery: "Tomava disciplina todos os dias, dormia pouco, passava horas inteiras m oração, e vestia muito pobremente" 32 .

Santa Rosa de Viterbo: "... desde pequena se entregou às maiores penitências e mortificações; andava cingida com ásperos cilícios, apertava-se com uma grossa corda, andava sempre descalça, jejuava muitas vezes..." 33 .

Desperta atenção também, outras práticas comuns entre os santos referidos, como a prática da peregrinação, da mendicância e desprezo às coisas mundanas. As hagiografias comumente terminam com a seguinte exortação: "Imitai, meus irmãos, imitai os Santos, que é um caminho seguro para o Reino dos Céus".

Evidentemente este breve comentário acerca da Missão Abreviada não esgota sua análise, apenas referenda algumas práticas e discursos que permeiam o universo religioso dos penitentes, notadamente dos Penitentes Peregrinos Públicos.

Mendigar em peregrinação é uma realidade que os Penitentes Peregrinos Públicos internalizaram a partir das imagens bíblicas e da Missão Abreviada, organizando sua realidade e práticas fundamentadas na pobreza e sofrimento para alcançar a redenção, espelhadas na vida de Jesus, e na Via Dolorosa. A Missão Abreviada é um documento revelador da origem de

\footnotetext{
${ }^{28}$ Op. cit., p. 581.

${ }^{29}$ Idem, p. 588.

${ }^{30}$ Idem, p. 593.

${ }^{31}$ Idem, p. 596.

${ }^{32}$ Idem, p. 599

${ }^{33}$ Idem, p. 601-602.
} 
muitos discursos dos Penitentes Peregrinos em várias passagens pudemos identificar uma cosmovisão convergente.

Observemos algumas aproximações desses discursos com o texto da Missão Abreviada:

"Não vos enganeis, meus irmãos; não vos enganeis com esse mundo; por quanto ele é um inimigo da alma; esse mundo tem enganado, e está enganando quase tudo; quase tudo ai perdido... ${ }^{34 "}$

"Nunca percas de vista este para sempre, meus irmãos; para sempre sepultados em camas de fogo lá no inferno; para sempre com os demônios; para sempre apartados de Deus, e privados do Reino dos Céus... ${ }^{35 "}$

Para os adeptos dessa Ordem, Jesus representa o modelo de penitente pois sofreu sem pecar, para a salvação dos homens. Neste sentido, é representado pelo universo cultural popular como um sofredor (penitente), a devoção refere-se ao Cristo Doloroso: crucificado, morto, flagelado - o Jesus da Paixão.

\section{Considerações Finais}

O catolicismo diferenciado praticado no Cariri cearense caracteriza-se por pautar-se pela experiência cotidiana de seus agentes produtores em contraposição ao instituído clericalmente. Esse universo cercado de misticismo, crença e fé, povoa o imaginário das camadas populares, entrando muitas vezes em conflito com o universo religioso institucionalizado. Paralelo ao pragmatismo dessas vivências religiosas, converge às práticas mágicas, cuja eficácia é materializada através da cura de enfermidades, obtenção de graças através de promessas e proteção por meio de relíquias, rosários ou outras peças mágicas. Observamos que estas práticas se apresentam polissêmicas, não havendo uma padronização que as definam como institucionalizadas. Pudemos observar também que as práticas do catolicismo diferenciado prescindem de um agente institucionalizado, sendo a ritualização gestual e oral expressões que religam o devoto ao sagrado.

\footnotetext{
${ }^{34}$ Op. cit., p. 170.

${ }^{35}$ Op. cit., p. 164.
} 
Algumas práticas e crenças são fundamentais para o entendimento do catolicismo diferenciado praticado no Cariri cearense e constituem a base de sustentação dos grupos religiosos estudados - autoflagelação, dança sagrada, mendicância, negação da modernidade, fundamentalismo religioso, devoção a santos populares, rígido código de ética social.

Enquanto produtor de sentido da existência grupal e individual, o simbólico adquire nesse contexto um sentido objetivo - de ser estar no mundo com um propósito - a salvação individual e coletiva.

A importância da Missão Abreviada e da Machadinha de Noé no seio de um grupo composto em sua maioria por iletrados revela-nos o quanto a oralidade e a memória são fontes expressivas de pesquisa e reconstrução de universos não letrados, dada a importância que a repetição discursiva e a ressignificação simbólica desses escritos que são repassados de geração a geração cumprem enquanto mantenedores e transmissores dessas experiências religiosas e atestam sua dinâmica e flexibilidade.

\section{Referências}

BÍBLIA SAGRADA. 26. ed. Tradução Centro Bíblico Católico. São Paulo:Ave Maria, 1979. p.1556. (Rodapé).

BOURDIEU, Pierre. A economia das trocas simbólicas. 5. ed. São Paulo:Perspectiva, 1999. . O poder simbólico. 2. ed. Rio de Janeiro:Bertrand Brasil, 1998.

BRITO, Gilmário Moreira. Culturas e linguagens em folhetos religiosos do Nordeste: interrelações, escrituras, oralidade, gestualidade, visualidade. 2001. 292f. (Doutorado em História Social) - Pontifícia Universidade Católica de São Paulo, São Paulo. Mimeografado.

CARVAlHO, Anna Christina Farias de. Sob o signo da fé e da mística: um estudo das irmandades de penitentes no Cariri cearense, 2005. 271f. (Doutorado em Sociologia) Universidade Federal da Paraíba, João Pessoa. Mimeografado.

CARVALHO, Gilmar de. Madeira matriz: cultura e memória. São Paulo:Annablume, 1998.

COUTO, Manoel José Gonçalves. Missão Abreviada: para despertar os descuidados converter os pecadores e sustentar o fructo das Missões. 6. ed. Porto:Tipographia de Sebastião José Pereira, 1868. 
Id on Line Revista Multidisciplinar e de Psicoloqia

Id on Line Multidisciplinary Journal and Psycology

CUNHA, Euclides. Os sertões: campanha de Canudos. São Paulo:Abril Cultural, 1982.

HOORNAERT, Eduardo. A Igreja no Brasil-colônia: 1550-1800. São Paulo:Brasiliense, 1982.

. Verdadeira e falsa religião no Nordeste. Salvador:Beneditina, 1972

MACHADINHA DE NOÉ. Folheto. s/d, s/l. Mimeografado.

MONTENEGRO, Abelardo F. Fanáticos e cangaceiros. Fortaleza:Henriqueta Galeno, 1973.

RAMOS, Francisco Régis Lopes. O meio do mundo: territórios de sagrado em Juazeiro do Padre Cícero. 2000. 350f. (Doutorado em História) - Pontifícia Universidade Católica de São Paulo, São Paulo. (Mimeo.).

SOUZA, Laura de Melo e. O diabo e a terra de Santa Cruz: feitiçaria e religiosidade popular no Brasil colonial. São Paulo:Companhia das Letras, 1986.

\section{Fontes Orais}

Entrevista com Mestre José Ave de Jesus, líder espiritual da Irmandade de Penitentes Peregrinos Público, Juazeiro do Norte-CE, datada de 08 de dezembro de 1998.

Entrevista concedida por Mestre José Ave de Jesus, líder espiritual da Irmandade de Penitentes Peregrinos Público, Juazeiro do Norte-CE, em maio de 1999.

Entrevista concedida por integrantes da Irmandade de Penitentes Peregrinos Público em 20 e 22 de agosto de 2002.

\section{Como citar este artigo (Formato ABNT):}

CARVALHO, A.C.F.; NASCIMENTO, M.C.D.; OLIVEIRA, G.F. Textos religiosos e práticas cotidianas: leitura de aspectos simbólicos da Irmandade de Penitentes Peregrinos Públicos - Juazeiro do Norte-CE. Id on Line Revista Multidisciplinar e de Psicologia, Set-Out/2016, vol.10, n.31, p. 221-240. ISSN 1981-1179.

Recebido: 14/08/2016.

Aceito: 20/08/2016 